\title{
International Responses to Human Rights Violations in Myanmar: The Case of the Rohingya
}

\author{
Jatswan S. Sidhu \& Syeeda Naushin Parnini
}

Abstract

While Myanmar is a multi-ethnic and multi-religious country, the Bamar (Burmese) nonetheless comprise almost 70 percent of the country's total population. Of the many ethnic groups in Myanmar, the Muslim Rohingya, are mainly centered in the Rakhine (Arakan) State, which borders Bangladesh. Although the position of these people as a distinct ethnic group was recognized by the U Nu government (1948-1962), the introduction of the 1982 Citizenship Act by the country's military government, however, have rendered them stateless. Subject to a wide range of systematic human rights violations by the Myanmar authorities, the Rohingya have often sought refugee in Bangladesh as well as many other countries in the region and beyond. Whilst most like-minded states and international organizations have duly responded to the issue, especially by providing humanitarian assistance and criticizing the Myanmar junta for its treatment of the Rohingya, however, much remains to be done to find a permanent solution to the issue of statelessness of these people. The purpose of this article is therefore to analyze responses from some segments of the international community over the issue of human rights violations on the Rohingya and the resulting exodus of these people from Myanmar. As such, this article will examine responses from Bangladesh, the Association of Southeast Asian Nations (ASEAN) and the regional community, the United States, the European Union (EU), the United Nations (UN) and the Organization of the Islamic Conference (OIC).

Keywords: Human Rights Violations, Myanmar, Rohingya, International Responses.

\section{Introduction: Human Rights Violations in Myanmar}

Myanmar (or formerly Burma) is a multi-ethnic and multi-religious country with eight major ethnic groups and 135 'national' or 'principled races'. The main ethnic groups comprise of the Bamar, Shan, Kachin, Kayin (Karen), Kayah (Karenni), Chin, Mon and Rakhine (Arakanese) (Mathews, 2001: 3). Although some 80 percent of the country's population practices Buddhism, there are also Christians, Muslims, Hindus and animists (Ministry of Information, Myanmar, 2002: 3-5). Politically, although the country practiced a Westminsterstyled democracy during its initial years after independence, from 1962 onwards, however, it was ruled by the military (tatmadaw), at least until 2011. In November 2010, an election was held and subsequently saw the formation of a new pseudo-civilian government. The new government is comprised of mostly former military men who had resigned their post to 
contest under the umbrella of the pro-junta Union Solidarity and Development Party (USDP), which won overwhelmingly in what was considered a highlyrigged election. Therefore, the 2 March 1962 military coup not only ended Myanmar's first and only experience with democracy, it even brought about the onset of systematic human rights violations by the country new rulers. Generally speaking, human rights violations in Myanmar can be broadly divided into three major categories namely thoseinflicted on the country's proponents of democracy, its ethnic and religious minorities (Amnesty International [AI], 2001)and the common man.

Myanmar's human rights performance has been extremely poor such that in 2010 alone, the country's human development index was at 0.451 , thus placing it at the 132 nd position out of the 169 countries surveyed by the United Nations Development Programme [UNDP] (UNDP, 2010). As for press freedom, in the 2010 World Press Freedom Index, Myanmar was ranked 174 of the 178 countries surveyed (Reporter Without Borders [RSF], 2010: 18), while the 2011 Global Peace Index placed the country at the 133 position of the 153

C countries surveyed - predominantly due to continued militarization, internal armed conflicts and human rights violations (Vision of Humanity, 2011). Further, in 2010, Myanmar was categorized as the second most corrupt country in the world by Transparency International (TI) and ranked at the 177 place, just above Somalia (TI, 2010: 3). Myanmar has also been classified by the Minority Rights Group as amongst the top five countries in the world where ethnic minorities are constantly under threat (Rogers, 2009), while the Freedom in the World 2010 report by Freedom House categorized the country as "the worst of the worst" for its abysmal human rights record (Allchin, 2010). On the wide array of human rights violations

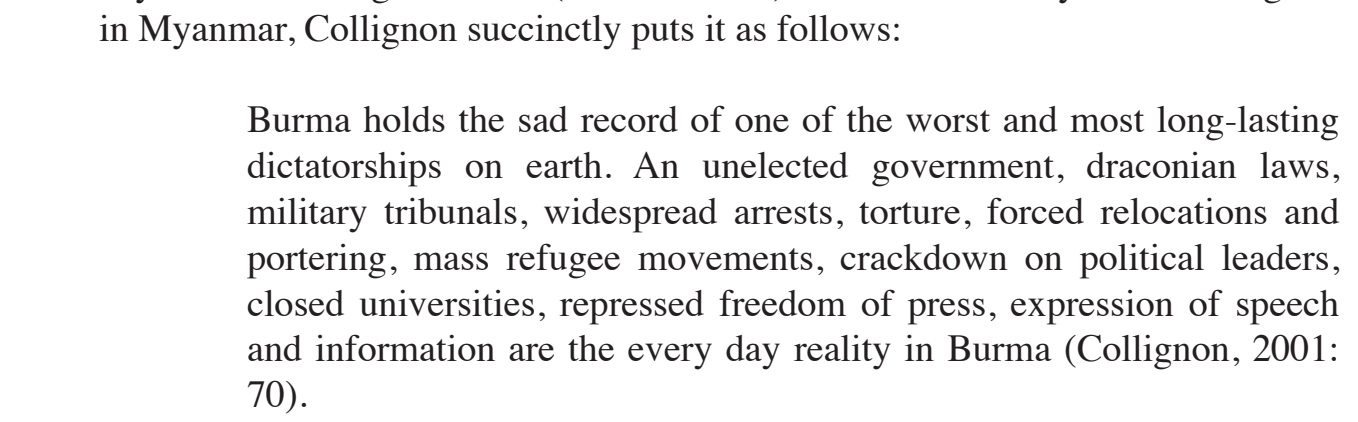

Burma holds the sad record of one of the worst and most long-lasting dictatorships on earth. An unelected government, draconian laws, military tribunals, widespread arrests, torture, forced relocations and portering, mass refugee movements, crackdown on political leaders, closed universities, repressed freedom of press, expression of speech 70).

In a similar tone, Fink asserts that:

Repression is not unique to Burma. Survival depends on submitting to those in power. Truth is often irrelevant. And people have to face choices that are hardly imaginable in a free society (Fink, 2001: 7).

\section{The Rohingya - A Persecuted Minority}

The Muslim Rohingya are amongst the many ethnic minorities found in Myanmar and are mainly located in the country's north-western Rakhine (Arakan) State.Although the origins 
of these people have been a subject of controversy, nonetheless, it was not until the onset of military rule in Myanmar in 1962 that the plight of these people became a subject of attention amongst transnational advocacy groups and like-minded states. While the $\mathrm{U} \mathrm{Nu}$ government did recognize the Rohingya as a distinct indigenous ethnic group, however, the military simply relegated them into a non-entity, especially through the introduction of the 1982 Citizenship Act. While the plight of Myanmar's many other ethnic minorities have received considerable attention from the academic community, the issue of the Rohingya. However, has received little concern thus far. In fact, the focus of the academic community appears to be on Myanmar's ethnic groups on the eastern front rather than its western borders (Lintner, 1990; Smith, 1991; Lintner, 1999; Tucker, 2000; Tucker, 2001; South, 2005).

Whilst the Myanmar government has continuously asserted that these people are Bengalis who have only recently migrated to Myanmar, mainly after independence in 1948, others, however, argue that the origins of the Rohingya date back to British rule when Muslims from Chittagong were brought in as laborers into the country. One source reiterates that, "while there is a serious debate as to whether the Rohingya represent one of Burma's historic ethnic nationalities, it is undisputable that they have lived in Burma for centuries" (Rogers, 2010: 104). However, since 1962, Myanmar's military government has consistently and categorically denied that the Rohingya in fact constitute an indigenous ethnic group. In a statement of 26 February 1992, Myanmar's Ministry of Foreign Affairs stated that:

In actual fact, although there are [135] national races living in Myanmar today, the so-called Rohingya people is not one of them. Historically, there has never been a 'Rohingya' race in Myanmar. The very name Rohingya is a creation of a group of insurgents in the Rakhine State. Since the First Anglo-Myanmar War in 1824, people of Muslim Faith from the adjacent country illegally entered Myanmar Ngain-Ngan, particularly Rakhine State. Being illegal immigrants they do not hold immigration papers like other nationals of the country (ALTSEANBurma, 2006: 2).

In fact, in 2009, one Myanmar official even went as far as labeling the Rohingya as people who were "ugly as ogres" (ALTSEAN-Burma, 2009: 3).As the second-largest ethnic group in the Rakhine State and comprising of almost 30 percent of the state's total population, most of the Rohingya live in the townships of Maungdaw, Buthidaung and Rathedaung, with them being the majority in the districts adjacent to Bangladesh as well as in the northern part of the state (Yeni, 2009: 19). Although it is difficult to estimate their total population, one source of 2002 puts the figure between 700,000 to 1.5 million (Smith, 2002: 18), while another claims that that were some 2 million Rohingya living in the Rakhine State in the past (Euro-Burma Office [EBO], 2009: 1). This is mainly due to the fact that not only are the Rohingyastateless citizens, even during periodic national census they are categorized as Rakhinesor simply omitted from the census. 
In October 1982, the country's new rulers enacted the Citizenship Law, which divided the people into three unequal class of citizens, namely full citizens, associate citizens and naturalized citizens. Full citizenship was accorded to people whose ancestors had domiciled in Myanmar prior to 1823, a year before the First Anglo-Burmese War, associate citizens were those whose ancestors had settled in the country during and after the war, while naturalized citizens were those who were born in the other countries. Nevertheless, the most important negative impact of this law was the nullification of the equal citizenship principal enshrined in the 1947 Constitution. By implicitly emphasizing the superiority of the Bamar (Burmese) over the country's many ethnic minorities, the law not only disenfranchised Myanmar's numerous ethnic groups but even marginalized them (Seekins, 2002: 121).

This new law was not only employed asa strategy for divide-and-rule but in reality reflected the xenophobia and distrust of Myanmar's military rulers over everything that was considered alien and foreign. It was based on this xenophobia that in 1978 - and prior to the enactment of the 1982 law - the Myanmar army launched an operation known as Naga Min (Dragon King) and the Hintha Plan in the Rakhine State, which was aimed at apprehending illegal migrants in the state. The brutal methods used by the army thus resulted in the exodus of some 200,000 Rohingya Muslims from the state into Bangladesh, mainly due to fears of a pogrom in the making. This was not the last, because subsequent military operations, even until the present, have resulted in the continuous exodus of large numbers of the Rohingya from the state. Since 1978, these people have been, subjected to a wide array of systematic human rights violations that include arbitrary detention and arrest, rape, mass killings, forced portering, forced labour, land confiscation, displacement and the like.For example, a source of 2002 noted that in 1994 alone, some 5,000 Rohingya youths were killed as they were Plabeled "anti-state elements" (Kalam, 2002). In addition, the Rohingya are also subjected - to discrimination such that they are not only denied access to education and healthcare - but are even required to obtain permission to marrysuchthat Muslim Rohingya women are only allowed to marry after they have reached the age of 18 and the men 24. As for - religious persecution, mosques and madrassas are not just routinely demolished but in place Buddhist shrines are often erected (Rogers, 2010: 104). For example, in 1996 alone, some 57 mosques and madrassas were demolished, while in May 2001, some 37 Muslim places of worship were simply destroyed in the township of Maungdaw (Kalam, 2002). Apart from being inflicted by the Myanmar army and police, these human rights violations against the Rohingya are also the work of the notorious Nasaka, the country's border security force.

Though many Rohingya have lived in the Rakhine State for generations, the 1982 law simply rendered them stateless. With no documentation, these people are also, prohibited from travelling within the country, what more going abroad, and especially to perform the haj. All the same, the military regime has also been sowing the seeds of hatred against these people especially amongst the Buddhist population in the state such that even the local Rakhines deeply resent the Rohingya.Coupled with this is the frequent outbreak of inter-communal violence against the Muslims by the Buddhists in the state - incidents that are also frequently orchestrated by the authorities - with one major incident unfolding in 
the capital, Sittwe (Akyab), in 2001 (Smith, 2002: 19). In this incident alone, some 150 houses belonging to the Rohingya, were simply burnt down (Kalam, 2002). On the role of the Myanmar authorities in sowing hatred against the Rohingya, one source confirms that:

Ultra-nationalists campaigns initiated by the Burmese government, often with the support of local Buddhists communities, have long portrayed the Rohingya as interlopers from neighboring Bangladesh and India, arguing that they are just another part of the negative legacy of British colonial rule (Yeni, 2009).

Rendered stateless, treated as temporary residents and subjected to a wide range of human rights violations, the Rohingya have no other option but to flee the country, such that large numbershave made way to Pakistan and even the Middle East.It is due to their statelessness that they have become to be known as the "New Palestinians" (Seekins, 2002: 122-123; Lintner, 1993: 24; Maung, 2009: 24-26). According to a source of 2009, there are currently some 500,000 Rohingya living in Saudi Arabia, 200,000 in Pakistan and some 50,000 in the United Arab Emirates [UAE] (EBO, 2009: 1). This is in fact in stark contrast with another source of 1993, which put the figure of Rohingyas in Saudi Arabia at 200,000 while those in the UAE were at 25,000 (Lintner, 1993: 23) - an obvious indication of the continuous exodus of these people.

Although international pressure on the Myanmar authorities have increased over the years, frequently calling on the former to find a solution to the problem of the Rohingya, the Myanmar government has to, a large extent, simply ignoredthese calls. The Myanmar government has consistently argued that the Rohingya would only be accepted back if they declare themselves as of Bengali origin. Nonetheless, in late 2010 and on the eve of the country's election, although the Myanmar government did issue temporary identity cards to all Muslims in the country, including the Rohingya, it was mainly aimed at wooing their votes. In fact, all of the country's Muslims are still required to carry with them Form 4 of the Immigration Department whenever they travel, even within the country.For the Human Rights Watch, this highly calculated persecution of ethnic minorities by the Myanmar government is considered an act akin to "systematic racism". Meanwhile, on the issue of the Rohingya, Refugees International considers these people as "one of the most persecuted in the world" (Allchin, 2011).

\section{Responses from the International Community}

Albeit that fact that Myanmar's human rights record deteriorated sharply from 1962 onwards, however, it was not until 1988 that its abysmal human rights record caught international attention. Since 1988, human rights violations in Myanmar have received ample attention from mainly like-minded Western states, transnational advocacy groups and even international organizations, namely the United Nations. In the light of these developments, issues pertaining to human rights violations in Myanmar have been raised by Western states 
and the United Nations, - either bilaterally or in multilateral forums - frequently calling on Myanmar's military junta to halt its human rights violations and improve its human rights record as well as undertake political change in the direction of democratization. As such, the following section will discuss responses from some states and international/regional organizations towards the Rohingya issue. These include Bangladesh, ASEAN and the regional community, the United States, the European Union (EU), the United Nations and the Organization of the Islamic Conference (OIC).

\section{Bangladesh}

As Myanmar's immediate western neighbor, Bangladesh has been impacted by the Rohingya issue in many ways. Not only has Bangladesh witnessed the exodus of thousands of Rohingya refugees into its territory, the issue has also had a negative impact in its relations with Yangon (Rangoon).Although Bangladesh has played host to the continued exodus of Rohingya refugees since the late 1970 s, nonetheless and due to limited resources to deal

With the problem, the country's authorities have often resorted to repatriation, even to the extent of forcibly pushing back these people. In fact, one strategy employed by Bangladesh has been literally to fortify its border with Myanmar, evident in the presence of a large number of its troops in that area. In response, even the Myanmar government has increased the presence of its troops along its border with Bangladesh, as a strategy to stall the latter's efforts in pushing the Rohingya back into Myanmar.In Bangladesh, most of these refugees live under deplorable conditions in makeshift squatter camps, which are often lack the most basic amenities such as clean water and healthcare (Lewa, 2003).

-

The first wave of the Rohingya refugees into Bangladesh began in 1978 such the latter was faced with its first and most serious refugee crisis since its independence in December 1971. Asecond wave of Myanmar refugees occurred in the aftermath of the 1988 demonstrations
when thousands of the country's dissidents fled the country into neighboring Bangladesh and - India. However, by March-April 1991, another major wave of Rohingya refugees arrived in Bangladesh when the Myanmar army undertook major counter-insurgency campaigns in the Rakhine State, which resulted in the displacement of thousands of Muslims. This flow continued well into the 1990s such that by July 1992 the number of Rohingya refugees in Bangladesh stood at 250,877 (Morshed, 2001: 60-62). According to Amnesty International, while the episode in 1978 witnessed some 200,000 Rohingya fleeing Myanmar into Bangladesh, the 1991-1992 military campaigns in the Rakhine State saw a quarter of million Rohingya leaving the country(AI, 2004: 5-6). Upon arrival in Bangladesh, most of these refugees were housed in ten camps along the road from Teknaf to Cox's Bazaar that was under the administration of the United Nations High Commissioner for Refugees [UNHCR] (Zaman, 1992).

Since then, Bangladesh has been faced with the continuous flow of Rohingya refugees from Myanmar. Although initially the Bangladesh government provided refugee for these people, however due to the dire economic situation in the country itself, it began negotiating with the 
Myanmar authorities for the repatriation of these people. In fact, the first memorandum of understanding between the governments of Bangladesh and Myanmar over the repatriation of the Rohingya was signed in April 1992. As this agreement only allowed for limited UNHCR involvement and as a result of international criticism, another memorandum of understanding was signed in May 1993, between Bangladesh, Myanmar and the UNHCR, which allowed for the involvement of the latter in the process. As for pushing back the Rohinga into Myanmar, one such incident was March 1996 when the Bangladesh government ordered its forces to push back or forcibly move the Rohingya. Currently, although the Bangladesh government claims that some 28,000 Rohingya refugees remain in the country, the unofficial figure stands at 220,000, with most of them unrecognized as refugees by Bangladesh (Médicine Sans Frontiéres [MSF], 2010).

\section{ASEAN and the Regional Community}

Apart from Bangladesh, the two Southeast Asian countries that have been impacted directly by the Rohingya issue are Thailand and Malaysia. As Myanmar's immediate neighbor on its eastern front, Thailand has been forced to bear the burden of hosting Myanmar's numerous ethnic refugees, especially whenever the Myanmar army launches its counter-insurgency efforts in areas bordering Thailand. Since 1962, Thailand has hosted a wide range of Myanmar's ethnic minorities namely the Kayins (Karens), Shans and Mons, not to mention the presence of a large number of Myanmar dissidents in the Thailand. It is estimated that Thailand is currently hosting some 150,000 refugees from Myanmar, which also include the Rohingya (AlertNet, 2011).

The Rohingya issue first caught the attention of the Southeast Asian regional community in the early 1990s when some 250,000 Rohingya fled Myanmar for Bangladesh due to persecution by the Myanmar army as a result of a military campaign in the Rakhine State. Commenting on the exodus, in March 1992, Malaysian Foreign Minister, Abdullah Ahmad Badawi, issued a strongly-worded statement when he was quoted as saying that the issue “could no longer be regarded as Burma's domestic problem because the action by Burmese troops has burdened neighboring countries and may disrupt regional stability" (ALTSEANBurma, 2009: 3). In a similar tone, Singapore's Foreign Ministry issued a statement that the mass exodus of refugees had the potential of creating an "area of instability for the region and human suffering" (ALTSEAN-Burma, 2009: 3).

However, after the 1992 incident, the plight of the Rohingya not only conveniently disappeared from the agenda of most Southeast Asian states, in fact, Myanmar was even admitted into the Association of Southeast Asian Nations (ASEAN) in 1997, in spite of its abysmal human rights record. Nonetheless, the issue flared-up once again on the eve of the 14th ASEAN Summit in 2009 when the plight of the Rohingya boat people caught international attention and that of the regional community. This was mainly due to the indifferent attitude of the Royal Thai Navy towards the Rohingya boat people appearing on its shores. It was reported that these boat people who had been appearing on Thailand's 
shores in engineless boats, had been towed by the Royal Thai Navy back into international waters. With little food and water, only a handful were eventually rescued close to India's Andaman Islands and Indonesia's Aceh province such that thousands simply perished at sea. According to one source, in June 2008 alone, some 8,000 Rohingya arrived in Thailand via boats, travelling from Bangladesh to Thai shores - often making these journeys by passing through Myanmar's waters and exposing them to the risk of being arrested under Section 13(1) of Myanmar's 1947 Immigration Act that stipulates on penalties for entering the country illegally (Yeni, 2009).

In one incident in early 2011, the Royal Thai Navy simply towed these helpless people back to sea, with such incidents frequently occurring over the last few years (Kaladan News, 2011a). When this high-handedness of the Royal Thai Navy created an outrage amongst some members of the international community, Thai Prime Minister, Abhisit Vejjajiva, in turn, pledged that an investigation would be launched into claims of cruelty of the country's navy against the Rohingya boat people (Bangkok Post, 2009).Despite this undertaking, (1) current evidence suggest that the Thai authorities still resort to high-handed tactics, especially when dealing with the Rohingya boat people. These Rohingya boat people often depart from either the coast of Myanmar's Rakhine State or Bangladesh, frequently making long and dangerous journeys in ill-equipped boats for Thailand's southern coast.

Upon arrival in southern Thailand, they then undertake long overland journeys southwards into Malaysia, such that these people have often been targeted by human trafficking syndicates. It is estimated that Malaysia currently hosts some 20,000 to 25,000 Rohingya refugees. However, as both Malaysia and Thailand are non-signatories to the 1951 Cunited Nations Convention Relating to the Status of Refugees or its 1967 protocol, these - refugees have simply no legal protection upon arrival in these states. Coupled with this is the restrictions imposed on representatives of the United Nations High Commissioner for Refugees (UNHCR) based in Bangkok and Kuala Lumpur by these states. Under such - circumstances, the Rohingya refugees are often subjected to a repeated cycle of arrest, detention and deportation in these two host countries, what more making them extremely vulnerable to exploitation (AI, 2010).

As for ASEAN, while some member-states have, on occasions, been critical of Myanmar's abysmal human rights record, the organization, on the whole, does not have a specific policy to deal with the issue. When the Rohingya boat people issue surfaced in January and February 2009 and on the eve of ASEAN's annual summit, ASEAN maintained its complete silence on the incident. Although initially, leaders from Malaysia, Indonesia and Thailand did agree to discuss the issue, it, however, never made to the regional organization's formal agenda. In turn, the issue was, passed on by ASEAN to the Bali Process for People Smuggling, Trafficking in Persons and Related Transnational Crime (Mathieson, 2009; Bangkok Post, 2009). Generally speaking, ASEAN has all along maintained its policy of non-interference when it comes to dealing with human rights violations in Myanmar, what more the plight of the Rohingya. 


\section{The United States}

Since 1988, the United States have been one of the most vocal critics of the Myanmar junta's abysmal human rights record. In the aftermath of the brutal crackdown of the 1988 peaceful demonstrations, the United States not only suspended all aid to the country, that remains in effect till today, it even is yet to appoint its ambassador to the country - a position that has been vacant since 1992. Thus far, the United States has imposed the most extensive sanctions against the Myanmar regime, which range from a ban on all new investments into the country to targeted financial sanctions against the top members of the Myanmar regime. All these are aimed at, firstly, pressuring the Myanmar regime to halt its human rights abuses and improve its human rights record, and secondly, for the Myanmar regime to undertake political change in the direction of democratization in the country (Deutz, 1991).

As for the Rohingya issue and apart from frequently criticizing the Myanmar junta on its treatment of these people, the United States has also been providing humanitarian assistance to the Rohingya refugees in Bangladesh since 1991. For example, in 2010 alone, the United States provided some US\$23 million to the UNHCR and the International Committee of the - Red Cross (ICRC), while some US\$1.28 million was allotted to various non-governmental organizations providing humanitarian assistance to these refugees in Bangladesh. This was reveled in June 2010, by Eric P. Schwartz, the United States Assistant Secretary for Bureau of Population and Migration,when he visited the Kutupalong refugee camp in Bangladesh (The Financial Express, 2011). During the visit, Schwartz also emphasized that the United States was against the forced repatriation of these refugees and asserted that the abysmal human rights conditions within Myanmar did not permit for the safe return of these people (The Daily Star, 2011; Kaladan News, 2011d).

Meanwhile, in October 2010, Congressman Christopher Smith (Republican - New Jersey) introduced a resolution in the United States House of Representatives calling on the Myanmar junta to grant "full and equal citizenship" to the Rohingya immediatelyand provide access to these people to education, aswell as remove all restrictions on them. He also urged the Myanmar junta to halt all forms of repression against ethnic and religious minorities as that was tantamount to crime against humanity. In addition, the resolution also called on the Bangladesh government to cooperate with the UNCHR in improving the living conditions of the Rohingya refugees. The resolution was introduced as a result of meeting between Congressman Smith and Maung Tun Khin, president of the Burmese Rohingya Organization United Kingdom (BROUK) which was facilitated by Christian Solidarity Worldwide [CSW] (Asian Tribune, 2010). In the meantime, in 2010, it was also reported that the first of some 800 Rohingya refugees were resettled in the United States - a number considered extremely small when compared to the other Myanmar ethnic minorities that had been resettled in the latter that amounts to more than 50,000 (Burma Rohingya Community Australia [BRCA], 2009). Apart from these initiatives, the United States is amongst the sixteen countries that have thus far supported the establishment of a United Nations-led Commission of Inquiry for war crimes and crimes against humanity to investigate human rights violations in Myanmar. 


\section{The European Union}

Like the United States, the European Union have also been the most ardent critic of Myanmar's abysmal human rights record such that it has often issued strongly-worded statements on human rights abuses in Myanmar.In fact, as a result of the brutal crackdown of the peaceful demonstrations in 1988, most European countries suspended aid to Myanmar. In 1991, the European Community - the predecessor of the European Union - imposed an arms embargo on Myanmar and, in 1991, suspended defense cooperation. The European Union's policy towards Myanmar is guided by the "EU Common Position on Myanmar", which was adopted in October 1996. It is based on this Common Position that the European Union has imposed sanctions, a visa ban on all high-level Myanmar officials and their families, and suspended all high-level visits to Myanmar. The Common Position was further strengthened in April 2000, when the European Union undertook additional measures against the Myanmar regime, which amongst others included a freeze on the assets of the top members of the Myanmar junta (Burma Centrun Nederland [BCM], 2011).

Apart from being a vocal critic of Myanmar's human rights record, the European Union has also been providing funds for humanitarian assistance for the Rohingya refugees in Bangladesh, which is channeled through the UNHCR.This is undertaken by the European Commission (EC), the highest decision-making body of the European Union. Since 1991, when the first mass exodus of the Rohingya refugees into Bangladesh started, the European Commission's Humanitarian Aid Department (ECHO) has provided some US\$54 million to the UNHCR for the purpose of humanitarian assistance for the Rohingya. In fact, in 2007 alone, the European Union allotted some $\square 3.9$ million (more than US\$5.7 million) for the Ssaid purpose, which was in fact double the amount allocated for 2006-2007. In addition, - it was with the support and pressure of the European Union that the UNHCR managed to - convince the Bangladesh government to effect improvements in the living conditions in two major Rohingya refugee camps, namely the Nayapara and Kutupalong camps (Mizzima - News, 2007). In fact, between 1997 and 2004, the European Union channeled some $\square 56.4$ million for the purpose of assisting Myanmar's uprooted people, namely by extending humanitarian assistance for refugees and internally displaced persons [IDPs] (European External Action Service [EEAS], 2006). Nonetheless, unlike the United States and some of its member-states, the EU has not official supported the formation of the Commission of Inquiry for war crimes and crimes against humanity in Myanmar.

\section{The United Nations}

The United Nations became involved in the human rights situation in Myanmar in 1990 when the first resolution calling on the Myanmar junta to improve its human rights record was issued by the United Nations General Assembly (UNGA). Since then, the UNGA has been issuing annual statements calling on the Myanmar authorities to remedy the situation. In addition, the United Nations Commission on Human Rights or UNCHR (presently known as the United Nations Human Rights Council or HRC) has also been directly involved in 
this issue. It was mainly due to the worsening human rights conditions in Myanmar that the UNCHR created the position of a Special Rapporteur on the situation on human rights in Myanmar in March 1992, which is given the task to investigate and report to the United Nations, on the human rights situation in Myanmar.

One United Nations agency that hasbeen directly involved in the Rohingya issue is the UNHCR. The UNHCR's involvement in the Rohingya issue dates back to February 1992, when the agency, together with some other international humanitarian organizations, created a broad relief operation in some 20 camps along the Teknaf-Cox's Bazaar Road in Bangladesh. As a result of negotiations between Bangladesh and Myanmar, in April 1992, a memorandum of understanding was signed between both countries for the repatriation of the Rohingya, which also allowed for the UNCHR's limited involvement. However, when between September and December 1992, the Bangladesh government resorted to forced repatriation of the Rohingya, the UNHCR withdrew and demanded that it be allowed interviews with the refugees. With pressure from the UNHCR and some segments of the international community, the Bangladesh authorities entered into negotiations with the UNHCR. As a result, in May 1993, a memorandum of understanding was signed between the Bangladesh government and UNHCR, which provided a protection guarantee for the Rohingya in camps and voluntary repatriation through interviews with the refugees. Further, in November 1993, the UNHCR signed a memorandum of understanding with the Myanmar government, which allowed the agency access to returnees, the issuance of identity cards and freedom of movement for these people. Further to this, in February 1994, the UNHCR was allowed a limited presence in the Rakhine State and only managed to obtain full access to all parts of the state by the end of 1994 (Médicine Sans Frontiéres [MSF], 1992: 5).

In the meantime, in August 1994and ahead of the December 1995 dateline for the repatriation of all Rohingya refugees, the UNHCR started a mass registration exercise for the refugees and managed to register some 176,000 Rohingya in Bangladesh. Based on the initiative by the UNCHR by mid-1996, the Bangladesh government approved the introduction of formal education activities in some of the Rohingya camps. Meanwhile, as the Bangladesh government continued with its repatriation policy - and at times by using force - the UNHCR began issuing protest notes to the authorities. It was probably based on these events that in January 1999, the UN agency began scaling down its activities, which was done also in view of the decision by the Bangladesh government to repatriate all Rohingya refugees and close down the camps by May 1999. Nonetheless, the UN High Commissioner for Refugees, Sadako Ogata, made a request to the Bangladesh government to allow for temporary status for the remaining refugees, with the right to work, education and healthcare,which was however rejected by the the latter. It was based on this decision that the UNHCR announced that it would remain in Bangladesh beyond May 1999 to cater to the needs of the remaining refugees. When in August 1994 the UNHCR announced its plans to implement a program on food for work for the Rohingya refugees, the Bangladesh government however strongly objected (MSF, 1992: 6). 
One major issue that the UNCHR had to tackle in these early years was that related to the chronic shortage of food for refugees. This was revealed in July 2000 when the World Food Programme (WPF) and the UNHCR jointly conducted a survey on the issue. It was found that almost 63 percent of the Rohingya refugee children under the age of five and some 56 percent of adult women were faced with chronic malnourishment. In addition, it was also discovered that many births amongst the Rohingya refugees had not been registered by the Bangladesh authorities, thus resulting in them not being entitled to food and medical care. It was based on these findings that the Bangladesh government, with the assistance of the UNHCR, eventually began registering all new births. After sorting out issues pertaining to the welfare of the Rohingya refugees in Bangladesh, in January 2002, the UNHCR announced its plans to revive the repatriation process (MSF, 1992: 7).

Due to the attitude of both the Bangladesh and Myanmar governments, the UNCHR has found its task of securing the welfare of the Rohingya an uphill battle. The frequent arrest, intimidation and exploitation of the Rohingya refugees in Bangladesh, coupled with the latter's non-recognition of new arrivals and forced repatriation are amongst the concerns that the UNHCR has been dealing with since its involvement in the issue. As for Myanmar, the uncooperative attitude of the country's authorities, coupled with its non-granting of full access to UNHCR's representatives in the Rakhine State has made the task even more complicated. It is therefore under these circumstances that the UNHCR only maintains its presence in two townships in the Rakhine State, namely in Maungdaw and Buthidaung.

\section{The Organization of the Islamic Conference (OIC)}

-

Cotit

As a body that represents the Muslim world, the OIC is another interested party that has been monitoring the situation of Myanmar's Rohingya. Due to the continuous persecution of the Rohingya in Myanmar and the resulting exodus of these people into Bangladesh, in June 2000, the OIC adopted a resolution criticizing the Myanmar junta for its human rights violations against Muslims in the country, and especially the Rohingya. Since then, the OIC has been issuing annual statements on the situation of the Rohingya and calling on the international community to intervene in the issue. In addition, it has also called on the international community to pressure the Myanmar authorities to introduce legal mechanisms for the protection of the rights of Muslims in the country (van Ten, 2005: 20-21).

On 9 June 2010, the OIC proposed for the formation of the Arakan Rohingya Union (ARU) as a body to coordinate and unite the efforts of the Rohingya. Further, in May 2011, the Secretary General of the OIC, Ekmeleddin Ihsanoglu, called on the Rohingya organizations to put up a united front in their struggle for better human rights (Kaladan News, 2011b). As a follow-up, in June 2011, the OIC hosted the first meeting for the ARU in Jeddah for the various Rohingya groups abroad and urged these groups to unite and coordinate their efforts. Apart from the presence of some 35 representatives from around 25 Rohingya organizations, the meeting was also, attended by representatives from the Brussels-based Euro-Burma Office [EBO] (Kaladan News, 2011c; Arakan Monthly, 2011: 2). 


\section{Conclusion}

From the preceding discussion, it can be concluded that while human rights violations in Myanmar has generally received ample attention from various segments of the international community, nonetheless there has been a sort of inertia when it comes to responses specifically on the Rohingya issue. This in turn gives an impression that while the international community has been extremely vocal on human rights violations against Myanmar's other ethnic minorities, it may appear that the reaction to the Rohingya issue has been limited. One reason for such an inertia relates to the fact that while most of the country's democracy proponents and ethnic minorities are well-linked to transnational advocacy groups, the Rohingya still lack such a connection in the said direction. Living in what is considered as the poorest state in an impoverished country (Yoshikawa \& Teff, 2011: 1), the Rohingya people are often denied access to education, such that many are illiterates. Contrary to the official claim by the Myanmar government that country enjoys literacy rates at 90 percent, a survey in the Rohingya refugee camps in Bangladesh revealed that only 12 percent could actually read and write (ALTSEAN-Burma, 2006: 5). What has probably further aggravated the situation relates to the fact that even the advocates of Myanmar's democracy movement, both from within and without, appear to have maintain a distance from the Rohingya issue. This evident in the fact that no Rohingya political organization, is party or a member of the many pro-democracy organizations, operating mainly from without (EBO, 2009: 3). This stand is also probably taken based on the consideration that should the democracy movement support the Rohingya cause they in turn might risk loosing support of the Rakhine State's majority Buddhist populace, what more the majority of the Buddhist in Myanmar.

\section{References}

UNHCR seeks access to Rohingya detained in Thailand. (2011, January 26). AlertNet. Retrieved from http://www.trust.org/alertnet/news/unhcr-seeks-access-to-rohingyasdetained-in-thailand

Allchin, J. (2010, January 13). Burma freedom is 'worst of the worst'. Democratic voice of Burma.

Allchin, J. (2011, September 1). Govt. reaffirms policy of racial profiling. Democratic voice of Burma.

ALTEAN-Burma. (2006). Rohingya and muslims in Arakan state: Slow-Burning Genocide. Bangkok: ALTEAN-Burma.

ALTEAN-Burma. (2009). Rohingya, asylum seekers and migrants from Burma: A human security priority for ASEAN. Bangkok: ALTSEAN-Burma. 
Amnesty International. (2001). Myanmar - Ethnic minorities: Targets of repression. London: Amnesty International.

Amnesty International. (2004). Myanmar - The Rohingya minority: Fundamental rights denied. London: Amnesty International.

Amnesty International. (2010). Abused and abandoned: Refugees denied rights in Malaysia. London: Amnesty International.

Thank you OIC, Thank you EBO. (2011). Arakan Monthly

Recognize Rohingyas as "full and equal citizens of Burma" urged US Congress. (2010, October 1). Asian Tribune.

Abhisit vows to address Rohingya cruelty claims. (2009, January 19). Bangkok Post.

(1)

Rohingya: A regional problem. (2009, February 22). Bangkok Post.

EU Sanctions. (2011). Burma Centrum Nederland. Retrieved from http://www. burmacentrum.nl

No place to go: Rohingya on the high seas. (2009, June). Statement from the BRCA, Lakemba, NSW: BRCA.

Collignon, Stefan. (2001). Human rights and the economy of Burma, in Robert H. Taylor (Ed.). Burma: Political Economy Under Military Rule. London: Hurst \& Co.

-

Deutz, Andrew. M. (1991, September). United States human rights policy towards Burma, 1988-91. Contemporary Southeast Asia, 13(2).

.

The Rohingyas: Bengali Muslims or Arakan Rohingyas. (2009). Euro-Burma Office Briefing Paper No. 2, Brussels: EBO.

Aid to uprooted people - programme activities: 1997-2006. (2006). Brussels: EEAS, European Union. Retrieved from http://eeas.europa.eu

Fink, Christina. (2001). Living silence: Burma under military rule. London: Zed Books.

Thailand towed Rohingya out to sea again, report voyagers. (2011, February 12). Kaladan News.

OIC calls on the Rohingya to unite. (2011, May 30). Kaladan News.

OIC held Rohingya convention to form ARU. (2011, June 3). Kaladan News. 
No forced repatriation of Rohingya refugees: Schwartz. (2011, June 13). Kaladan News.

Kalam, Hajee M. A. (2002, January 25). Tragedy of the Rohingyas: How long will they suffer. The Independent.

Kyaw, Nyi Nyi. (2008). Myanmar's forgotten people. Forced Migration Review. 30.

Lewa, C. (2003). We are like a soccer ball, kicked by Burma, kicked by Bangladesh!. Bangkok: Forum-Asia.

Lintner, B. (1993, January 28). Distant exile: Rohingyas seek new life in Middle East. Far Eastern Economic Review.

Lintner, B. (1990). Land of Jade: A Journey through Insurgent Burma. Bangkok: Kiscadale White Lotus.

Lintner, B. (1999). Burma in revolt: Opium and insurgency since 1948. Bangkok: Silkworm Books.

Mathews, B. (2001). Ethnic and religious diversity: Myanmar's unfolding nemesis. Visiting Researchers Series No. 3, Singapore: Institute of Southeast Asian Studies (ISEAS).

Mathieson, D. S. (2009, May 25). In ignoring the Rohingyas, ASEAN rejects a new role, The Jakarta Globe.

Maung, Min Khet. (2009). Burma's Gaza?. The Irrawaddy, 17 (17, 2), March-April.

(1992). 10 years for the Rohingya refugees in Bangladesh: Past, present and future. Amsterdam: Medicines Sans Frontieres - Holland.

(2010). Bangladesh: Violent crackdown fuels humanitarian crisis for unrecognized Rohingya refugees. New York: Medicines Sans Frontieres. Retrieved from http:// www.doctorswithoutborders.org

Myanmar: EU provides 3.9 million euros for Rohingya refugees. (2007, December 7). Mizzima News.

Morshe, K. (2001). Bangladesh-Burma Relations. Challenges to democratization in burma: perspectives on multilateral and bilateral responses. Stockholm: International Institute for Democracy and Electoral Assistance (International IDEA).

Yangon: Ministry of Information, Union of Myanmar. (2002). Myanmar: Facts and figures 2002. 
(2012). 2010 World Press freedom index. Paris: Reporters Without Borders (RSF).

Rogers, B. (2009, December 17). Where impunity reigns. The New York Times.

Rogers, B. (2010). Than Shwe: Unmasking Burma's tyrant. Chiang Mai: Silkworm Books.

Seekins, D. M. (2002). The disorder in order: The army-state in Burma since 1962. Bangkok: White Lotus.

Smith, M. (1991). Burma: Insurgency and the politics of ethnicity. London: Zed Books.

Smith, M. (2002). Burma (Myanmar): The time for change. London: Minority Right Group International.

South, A. (2005). Mon Nationalism and civil war in Burma. London: Routledge.

Colution to Rohingya issue lies in Myanmar: US. (2011, June 9). The Daily Star.

US assures continued support for for Rohingya refugees. (2011, June 10). The Financial Express

(2010). Corruption Perception Index 2010. Berlin: Transparency International.

Tucker, S. (2000). Among insurgents: Walking through Burma. London: Penguin.

Tucker, S. (2001). Burma: The curse of independence. London: Pluto Press.

(2010). Myanmar - country profile of human development indicators. New York: United

Nations Development Programme Retrieved from http://hdrstats.undp.org

- Yeni. (2009). Unwanted anywhere. The Irrawaddy, 17 (2).

Yoshikawa, L., \& Teff, M. (2011). Bangladesh: The silent crisis. Field Report, Washington D.C.: Refugees International (RI).

Van Ten, Rianne. (2005). Myanmar's Muslims: The oppressed of the oppressed. London: Islamic Human Rights Commission (IHRC).

Vision of Humanity. (2011). Global Peace Index GPI Map - 2011. Sydney: Vision of Humanity. Retrieved from http://www.visionofhumanity.org/

Zaman, R. (1992, April 15). Tragedy of the Rohingyas unfold. New Straits Times. 